\title{
Clinical application of exhaled nitric oxide measurement in pediatric lung diseases
}

\author{
Angelo Manna', Carlo Caffarelli², Margherita Varini², Carlotta Povesi Dascola², Silvia Montella', Marco Maglione', \\ Francesco Sperlì ${ }^{1}$ and Francesca Santamaria ${ }^{1 *}$
}

\begin{abstract}
Summary
Fractional exhaled nitric oxide (FeNO) is a non invasive method for assessing the inflammatory status of children with airway disease. Different ways to measure FeNO levels are currently available. The possibility of measuring FeNO levels in an office setting even in young children, and the commercial availability of portable devices, support the routine use of FeNO determination in the daily pediatric practice. Although many confounding factors may affect its measurement, FeNO is now widely used in the management of children with asthma, and seems to provide significantly higher diagnostic accuracy than lung function or bronchial challenge tests. The role of FeNO in airway infection (e.g. viral bronchiolitis and common acquired pneumonia), in bronchiectasis, or in cases with diffuse lung disease is less clear. This review focuses on the most recent advances and the current clinical applications of FeNO measurement in pediatric lung disease.
\end{abstract}

Keywords: Exhaled nitric oxide, Children, Airway diseases, Asthma, Bronchiolitis, Community acquired pneumonia, Bronchiectasis, Diffuse lung disease

\section{Introduction}

Nitric oxide (NO) is a biological mediator synthesized by NO synthase (NOS), an enzyme that catalyzes the oxidation of L-arginine to $\mathrm{NO}$ and L-citrulline. Constitutive NOS isoenzymes include neuronal NOS (NOS1) and endothelial NOS (NOS3), both of which are activated by calcium ions to produce small amounts of NO [1]. Inducible NOS (NOS2), that is induced by inflammatory and infectious stimuli, produces large amounts of NO independent of calcium ion influx [2]. NO was first described as a vascular smooth muscle relaxant and was subsequently found to be present in the expired breath of animals and humans [1]. In the lungs, NO determines smooth muscle relaxation, affects ciliary beat frequency, mucus secretion and plasma exudation, and is involved in neurotransmission, blood flow regulation, inflammation and cell-mediated immunity processes [3]. In the upper respiratory tract NO levels are higher than in the lower airways, with the maximal concentration in the

\footnotetext{
* Correspondence: santamar@unina.it

'Department of Pediatrics, Federico II University, Via Sergio Pansini, 5 80131, Naples, Italy

Full list of author information is available at the end of the article
}

paranasal sinuses, probably because of local increased NOS activity and of poor ventilation [4].

During the last years the availability of $\mathrm{NO}$ analyzers and the publication of official guidelines made the measurement of fractional exhaled $\mathrm{NO}$ (FeNO) a useful tool in the diagnosis of various pediatric airway disorders [5-10]. This review summarizes the most recent advances and the current clinical applications of FeNO measurement in the pediatric clinical practice.

\section{How should FeNO be measured?}

Several methods are used to measure FeNO in children, and the choice depends on the subject's age and cooperation. Online measurement allows FeNO testing with a real-time display of $\mathrm{NO}$ breath profiles, which is available in stationary devices only. Offline testing, instead, refers to collection of exhaled air into suitable receptacles for delayed analysis [5]. The single breath online measurement is the gold standard in school-age children [5,11]. The subject is asked to inhale to near total lung capacity and to exhale at a constant flow of $50 \mathrm{~mL} / \mathrm{s}$ until a $\mathrm{NO}$ plateau of at least 2 seconds can be identified. The offline method with constant flow rate is the offline method of choice in school-age children [5]. The child blows air through a 
mouthpiece into a receptacle. Nasal contamination is prevented by closing the velum by exhaling against at least 5 $\mathrm{cm} \mathrm{H}_{2} \mathrm{O}$ oral pressure. $\mathrm{NO}$ concentrations in balloons can be stable for several hours, and the measurement can take place also at a distant site. Flow rate standardization improves the reproducibility of the offline technique, with results similar to the online constant flow rate methods [11]. In subjects younger than 5 years, single-breath online measurement is not well standardized since children cannot adequately cooperate. In the age group from 2 to 5 years, FeNO levels are measured online during spontaneous breathing, with the exhalation flow adjusted to $50 \mathrm{~mL} / \mathrm{s}$ by changing the exhalation resistance [12]. The child breathes quietly, slowly and regularly through a mouthpiece connected to a two-way valve. NO-free air is continuously flushed through the inlet of the valve. However, NO levels measured during spontaneous breathing may not equate with single-breath online measurements. In children younger than 2 years, the tidal breathing method has been used both online and offline, but it is not standardized [11].

Finally, the agreement between different devices gave inconsistent results, with some studies showing significant differences between analyzers [13], while others showed a high degree of agreement between different devices [14-16]. In particular, a recent study demonstrated an acceptable degree of agreement only between devices from the same manufacturer, both stationary and portable [17].

\section{FeNO reference values in exhaled air}

Several recent publications have reported reference values for FeNO in children and adolescents [18-28] (Table 1). There are important differences among these studies regarding to the size of the examined population as well as the range of statistical variables that have been included or excluded, limiting their value. Several factors may affect FeNO levels: measurement techniques, exhalation flow rate, nasal NO contamination, NO analyzer used, race, age, sex, atopy, anthropometric measures, smoking, and diet. While some of these (height, age, smoke, atopy) are universally accepted as crucial in increasing FeNO values [20,29], there is uncertainty regarding the others [30-32].

\section{FeNO and bronchial asthma}

\section{FeNO in the diagnosis of bronchial asthma}

Chronic airway inflammation is an important feature in the development and progression of bronchial asthma [10,33-36]. FeNO levels are increased in asthmatic patients [37-39] as a result of induction of NOS2 by proinflammatory cytokines [3,40-43]. There is some degree of correlation between elevated FeNO levels and increased eosinophils in blood, bronchoalveolar lavage fluid [28], bronchial biopsies [44], sputum [45], this indicating that FeNO reflects eosinophilic inflammation [28,33,46,47]. However, asthma is probably not a single disease since at least 3 adult phenotypes of airway inflammation have been identified on the basis of predominant eosinophilic, neutrophilic, or pauci-granulocitic cellular pattern [48]. It is therefore not surprising that the difference in FeNO levels between symptomatic and asymptomatic children is relatively small, and a large overlap in the distribution of FeNO levels from subjects with and without asthma has been reported [49-58] (Table 2). Another limitation is that even though FeNO is increased in children with allergic asthma [59-62], the obtained levels cannot discriminate among schoolchildren with non-allergic asthma, or those with allergy without asthma, or the healthy population [63]. Moreover, levels of FeNO appear increased in asthmatics with pollen allergy during the season also in the absence of symptoms of lung function impairment [64].

Table 1 FeNO reference values in healthy children and adolescents

\begin{tabular}{|c|c|c|c|c|}
\hline Author [reference] & $\mathrm{N}$ & Subjects & Normal values* & Analyzer \\
\hline Dötsch 1996 [24] & 37 & Caucasian, $4-18$ years & $3.1 \mathrm{ppb}$ & CLD 700; Eco Physics, Dürnten, Switzerland \\
\hline Baraldi 1999 [18] & 159 & Caucasian, 6-15 years & $8.7 \mathrm{ppb}$ & CLD 700, Al-Med, Ecophysics, Durnten, Switzerland \\
\hline Silvestri 1999 [25] & 22 & Caucasian, 11-12 years & $4.0 \mathrm{ppb}$ & LR 2000, Logan System, Rochester, Kent, UK \\
\hline Franklin 1999 [26] & 157 & Caucasian, $7-13$ years & $7.4 \mathrm{ppb}$ & NOA 280, Seivers Instruments Inc., Boulder, CO \\
\hline Latzin 2002 [27] & 107 & Caucasian, $4-18$ years & $9.2 \mathrm{ppb}$ & LR 2000, Logan Research, Rochester, UK \\
\hline Jouaville 2003 [28] & 96 & Caucasian, 9-10 years & $13.3 \mathrm{ppb}$ & Sievers Instruments, Boulder, CO, USA, kit bag collection \\
\hline Buchvald 2005 [19] & 405 & Caucasian, Hispanic, Asian, Black, 4-17 years & $9.7 \mathrm{ppb}$ & NIOX, Aerocrine AB, Stockholm, Sweden \\
\hline Wong 2005 [21] & 291 & $\begin{array}{l}\text { Chinese, } 11-18 \text { years } \\
\text { Caucasian, } 11-18 \text { years }\end{array}$ & $\begin{array}{l}19.9 \mathrm{ppb} \\
12.7 \mathrm{ppb}\end{array}$ & NIOX, Aerocrine AB, Stockholm, Sweden \\
\hline Malmberg 2006 [22] & 114 & Caucasian, $7.2-15.7$ years & $\begin{array}{l}\text { Mean values } \\
\text { not reported; } \\
\text { range } 7-14 \mathrm{ppb}\end{array}$ & NIOX, Aerocrine AB, Stockholm, Sweden \\
\hline Kovesi 2008 [20] & 657 & White, Black, Asian, 9.1-12.9 years & $12.7 \mathrm{ppb}$ & CLD 88sp, Eco Medics AG; Durnten, Switzerland \\
\hline Yao 2012 [23] & 693 & Asiatic, $5-18$ years & $13.7 \mathrm{ppb}$ & CLD 88sp, Eco Medics AG; Durnten, Switzerland \\
\hline
\end{tabular}

*Expressed as mean values. 
Table 2 Diagnostic accuracy of FeNO measurement in patients with asthma

\begin{tabular}{|c|c|c|c|c|c|}
\hline Author [reference] & Subjects & Patients with asthma (\%) & FeNO cut-point & Sensitivity (\%) & Specificity (\%) \\
\hline Malmberg 2003 [58] & Children, 3-7 years & $83(25)$ & $>9.7 \mathrm{ppb}$ & 86 & 92 \\
\hline Dupont 2003 [50] & Adults & $160(66)$ & $>16 \mathrm{ppb}$ & 49 & 90 \\
\hline Berkman 2005 [57] & Adults & $40(47)$ & $>7 \mathrm{ppb}$ & 82 & 89 \\
\hline $\begin{array}{l}\text { Sivan } 2009 \text { [51] } \\
\end{array}$ & Children, $12-18$ years & $106(70)$ & $>19 \mathrm{ppb}$ & 86 & 89 \\
\hline Sachs-Olsen 2010 [52] & Children, $10-12$ years & $60(45)$ & $>20.4 \mathrm{ppb}$ & 41 & 97 \\
\hline Pérez Tarazona 2011 [53] & Children, 6-14 years & $57(40)$ & $>19 \mathrm{ppb}$ & 91 & 87 \\
\hline Yao 2011 [54] & Children, 5-18 years & $70(4.5)$ & $>28 \mathrm{ppb}$ & 64 & 70 \\
\hline Cordeiro 2011 [55] & Adults, Children & $42(30)$ & $>27 \mathrm{ppb}$ & 78 & 92 \\
\hline Woo 2012 [56] & Children, 8-16 years & $167(68)$ & $>22 \mathrm{ppb}$ & 57 & 87 \\
\hline
\end{tabular}

Children with atopic eczema exhibit high levels of FeNO even though they do not have asthma [65], but the mechanism is unclear.

Obesity is another confounding factor in the assessment of FeNO levels. A consistent body of data now indicates that asthma is closely related to obesity, and obese patients with asthma usually have more severe symptoms than nonobese asthmatics [66]. Indeed, obese asthma may be a unique phenotype that is characterized by more severe symptoms for a given degree of lung function impairment, destabilization or lack of asthma control, worse quality of life, lack of eosinophilic inflammation and a different response to controller medication [67]. At any age, obesity can adversely impact on lung function, and obesity duration is a determinant of lower pulmonary function [68]. FeNO levels have been extensively investigated in pediatric excess adiposity $[9,69]$. Some pediatric studies showed that FeNO is negatively associated with body mass index, waist-to-hip ratio, and percent body fat [70], while others found no relationship between FeNO levels and adiposity measures $[69,71]$. Furthermore, FeNO levels do not differ between obese and normal weight subjects with asthma [9]. A possible explanation for this results might be a selection bias, in particular overdiagnosis of asthma attributable to non specific obesity-related respiratory symptoms among obese children. Indeed, recent meta-analyses have pointed out that some obese patients with "asthma" may have respiratory symptoms caused by obesity without objective physiological criteria for asthma, or an exaggerated symptom perception [72].

As far as the discrimination between children with asthma and healthy subjects, FeNO measurement provides significantly higher diagnostic accuracy than lung function tests [58,73], and has diagnostic value comparable to that of conventional bronchial challenge tests [57]. Several studies showed an inverse correlation between FeNO levels and bronchial hyperreactivity tests in children [58,70-76], and only one group did not confirm this finding [77]. Nevertheless, elevated FeNO levels increase the probability of exercise-induced bronchoconstriction in asthmatic school-age children [78]. These conflicting results may be explained with the different methods used to measure FeNO as well as with the heterogeneity of the study populations, in particular regarding the presence of atopy and the use of steroids.

Cut-points rather than reference values have been proposed to interpret FeNO levels [33,34,72,79]. In children, FENO values less than $20 \mathrm{ppb}$ indicate that eosinophilic inflammation is less likely, or that in patients presenting with non specific respiratory symptoms alternative diagnoses to asthma should be considered [79]. High FeNO concentration ( $>35 \mathrm{ppb}$ in children) strongly suggests significant airway eosinophilia [79]. At high expiratory flows, ranging from 200 to $280 \mathrm{~mL} / \mathrm{s}$, the negative and positive predictive values for FeNO $>25 \mathrm{ppb}$ as predictor of asthma rise to $80 \%$ and $100 \%$, respectively [80]. Nonetheless, intermediate FeNO levels (20-35 ppb in children) indicate that cautious interpretation in the etiology of the airway disorder is required.

An additional, novel, potential and attractive application of FeNO in asthma is the "prediction" of asthma onset. In the absence of symptoms, increased FeNO levels may reflect subclinical airway inflammation that may be predictive of "early asthma", especially in allergic subjects [81,82]. This could be explained by an enhanced Th2 cytokine-driven airway response in allergic individuals that may precede the clinical presentation. Furthermore, in asymptomatic adolescents, increased FeNO may predict the development of rhinitis symptoms within a follow-up period of 4 years [83], suggesting that FeNO may be a sensitive biomarker of the "allergic march". These findings have potential clinical and therapeutic implications, also because studies in animal models seem to show a possibility to block induction of Th2 responses, thus preventing the development of future asthma [84].

\section{FeNO in the follow-up of bronchial asthma}

The goal of asthma long-term treatment is to reduce inflammation for controlling symptoms. Treatment options are usually guided by symptoms and lung 
function. However, these factors do not reflect chronic airway inflammation. This is also shown by contrasting results of studies on the relationship between FeNO levels and both symptoms (including recent symptoms, symptom frequency, symptom scores), symptom control, or rescue $ß 2$-agonist use [77,85-94] and pulmonary function test results $[25,85-87,89,91,93-100]$.

Inhaled corticosteroids (ICS) are the first choice for asthma maintenance treatment. Interestingly, inhaled or systemic corticosteroid administration results in dose dependent reductions of FeNO levels [27,100]. Moreover, in corticosteroid-naïve patients with suspected asthma, the baseline FeNO value may predict an ICS response in terms of improved lung function and reduced airway reactivity [73]. Therefore, FeNO seems a suitable biomarker for modifying ICS dose in order to obtain better asthma control [101]. However, in children, daily monitoring of FeNO at home [102], as well as measurement of FeNO levels every 3 months for 1 year [103], or 5 times in 6 weeks [104] do not provide any advantage in improving the symptom score. In adolescents and adults, Szefler et al showed that the addition of FeNO measurement as an indicator of asthma control resulted in higher doses of ICS and long-acting $\beta 2$ agonists than did standard guideline-based treatment, and did not determine improvements in asthma symptoms or lung function [105]. A recent meta-analysis concluded that the number of asthma exacerbations is not significantly reduced in adults and children when ICS was tailored based on FeNO [106].

These findings may be explained by the fact that day-to-day variations of FeNO are common and do not correlate with changes in symptom score [107]. Furthermore, some atopic asthmatic patients showed a lack of FeNO responsiveness to ICS [108,109], or may have increased FeNO levels despite high dose ICS [110].

Another issue is whether the change in FeNO values may be a better predictor than absolute levels. FeNO levels quickly decrease in response to ICS and therefore they may be useful to ascertain that ICS is regularly taken. Finally, baseline FeNO seems a worse predictor of asthma improvement than the change in FeNO after 80 days of ICS [111].

According to the Clinical Practice Guideline of the American Thoracic Society (ATS) [79] it has been suggested to consider as significant the increase in FeNO greater than $20 \%$ for values over $50 \mathrm{ppb}$, or more than $10 \mathrm{ppb}$ for values lower than $50 \mathrm{ppb}$ from one visit to the next. The second one recommends to use a reduction of at least $20 \%$ in FeNO for values over 50 ppb (or more than $10 \mathrm{ppb}$ for values lower than $50 \mathrm{ppb}$ ) as the cut point to indicate as significant the response to antiinflammatory therapy.
The results of two recent studies indicate new possible clinical applications of FeNO measurement in pediatric asthma. Pifferi et al assessed the value of spirometry and FeNO measurements, alone or in combination, in models developed by a machine learning approach for the objective classification of asthma control [112]. The combined use of spirometry parameters and FeNO levels modeled by a soft computing learning approach applied to spirometry could discriminate the level of asthma control. Van der Valk et al found that FeNO measured daily by a hand-held device started to increase approximately 10 days before moderate exacerbations occurred, this suggesting that regular FeNO measurements in the home setting could help to detect and even to prevent the loss of asthma control [113]. Apart from ICS, other established controller therapies, such as leukotriene modifiers or anti-IgE therapy with omalizumab, have been demonstrated to reduce FeNO in children, alone or combined with ICS [114-117].

On the basis of the studies that have provided evidence regarding the applications of NO measurements in clinical practice, ATS recently indicated the rationale for FeNO measurement in asthma, even in the pediatric population [79], highlighting the following situations:

- Diagnosis of eosinophilic airway inflammation

- Support of asthma diagnosis when objective evidence is needed

- Baseline evaluation and follow-up monitoring of airway inflammation

- Assessment of potential response or failure to respond to inhaled corticosteroids

- Evaluation of adherence to antiinflammatory medications

- Guide for dose changes in antiinflammatory medications

\section{FeNO in viral bronchiolitis}

Respiratory Syncytial Virus (RSV) manifests restricted tropism for the respiratory epithelium stimulating an inflammatory response [118]. RSV increases NOS2 messenger RNA, and upregulates NOS2 and its nitrite products in lines and cultures of respiratory epithelial cells [119-121]. Despite in vitro and animal data demonstrated NO involvement in bronchiolitis [120, 122], only few studies evaluated FeNO levels in children with RSV bronchiolitis. Surprisingly, FeNO appeared significantly lower in infants with bronchiolitis than in healthy controls or in preschool children with recurrent wheezing [123]. However, the same study demonstrated that 3 months after the diagnosis of RSV bronchiolitis, FeNO appeared significantly higher in affected children than in normal subjects, suggesting that low FeNO reflects the active suppression of NO production occurring during the active infection, while the increased 
levels might be interpreted as a "rebound" phenomenon. Future studies will hopefully provide more insights on the relationship between viral infections and subsequent chronic bronchial asthma.

\section{FeNO in community acquired pneumonia}

The scientific literature on FeNO modifications during community acquired pneumonia (CAP) in children is scarce. Since NO is part of the innate inflammatory response, its levels are expected to rise in acute lung infection. Healthy children with an abnormally high FeNO had significantly increased frequency of previous bronchitis or pneumonia in the past year [124]. However, Carraro and colleagues measured FeNO three times over a 1 month period in the exhaled breath condensate obtained from children with chest $\mathrm{x}$-ray evidence of CAP, and found no significant differences in FeNO levels either from children with CAP compared to healthy controls, or from baseline levels during the follow-up [125]. Different hypotheses might explain this paradox. First, NO output from expiratory flows of $50 \mathrm{~mL} / \mathrm{s}$ mainly derives from airway $\mathrm{NO}$ diffusion, and therefore at higher flow rates, that sample from the deeper parts of the lung, higher NO levels might be found. Second, NO might also react rapidly with reactive oxygen species, forming NO-metabolites. Unfortunately, the above mentioned data do not allow to reach definitive conclusions, and highlight the need for further studies on the role of FeNO in children with CAP.

\section{FeNO in bronchiectasis}

Bronchiectasis is caused by, or associated with, many disorders including congenital/genetic conditions, e.g. cystic fibrosis (CF), primary immunodeficiency, primary ciliary dyskinesia (PCD), Mounier-Kuhn syndrome, chronic obstructive pulmonary disease, bronchiolitis obliterans, sarcoidosis, autoimmune disorders, and acquired postinfectious diseases [126-131]. High-resolution computed tomography (HRCT) is the gold standard for the diagnosis $[128,132]$, even though radiation, magnetic resonance imaging has been proposed as an alternative radiation-free technique, especially in children [133, 134].

Levels of inflammation in stable bronchiectasis seem to correlate with a reduction of patient's quality of life [135]. Therefore, monitoring inflammation is of outstanding relevance in the management of affected patients, especially for preventing the disease progression. Since current markers of inflammation in the blood and in the sputum are indirect, variable and invasive, FeNO measurement may represent a useful way to assess airway inflammation in patients with bronchiectasis. Some studies found that FeNO levels from adults with non-CF, non-PCD bronchiectasis are significantly higher compared to controls [136-138], but others did not confirm this $[80,139,140]$. In children with bronchiectasis due to CF or PCD, FeNO levels are abnormally low compared to non CF- non PCD-patients or to controls, but there are no significant differences between PCD and CF [80,141-143].

$\mathrm{NO}$ measurement at different expiratory flow rates allows to assess the contribution of NO from different parts of the lung. A two-compartment model of pulmonary NO exchange dynamics has been proposed to demonstrate relative contributions of bronchial $(\mathrm{J})$ and peripheral (Calv) airway NO to the final FeNO concentration [144]. In adults with non CF- non PCD- bronchiectasis an increase in CalvNO with normal JNO levels has been recently demonstrated [136]. In children with CF-related bronchiectasis results appear conflicting, with one study showing lower JNO in CF than controls and no difference in CalvNO between groups [145], whereas other authors demonstrated that children with CF had a significantly higher CalvNO, but no significant difference in JNO compared to healthy children [146]. On the other hand, in children with PCD, very low levels of nasal NO are still a partially unexplained feature, whereas FeNO levels show considerable overlap with healthy subjects [80]. Paraskakis and colleagues found that in children with PCD JNO was significantly reduced, but CalvNO was normal compared with healthy controls [147]. On the basis of these findings, authors speculate that the normal CalvNO values militate against a generalized disorder of $\mathrm{NO}$ metabolism in PCD children, and hypothesize that NOS3 (endothelial) has normal function in PCD, while the uncoupling of the contractile process of the cilia from NOS2 (inducible) may result in failure of NO production.

Notwithstanding the conflicting results between affected children and adults, FeNO measurement could represent a useful non invasive tool to monitor bronchial inflammation over time.

\section{FeNO in diffuse lung disease}

The term diffuse lung disease (DLD) encompasses a heterogeneous group of chronic respiratory disorders characterized by abnormal gas exchange and diffuse radiographic and histopathologic abnormalities [148]. DLD is rare in children, and diagnosis requires detailed history, complete physical examination, lung imaging, pulmonary function testing, bronchoalveolar lavage (BAL), and in most cases an open lung biopsy to confirm the suspicion [148,149].

Several studies evaluated FeNO levels in adults with DLD. In systemic sclerosis, FeNO concentrations are lower in subjects with interstitial lung involvement than in those without, whereas patients without pulmonary disease have higher FeNO than healthy subjects [150]. Moreover, FeNO levels seem to be increased in subjects with asbestosis [151], but not in pulmonary sarcoidosis [152]. To the best of our knowledge, no studies ever evaluated FeNO levels in children with DLD. This would 
likely be crucial in the management of these critical conditions, hopefully being useful in the evaluation of the progression of the disease, or of the response to treatment.

\section{FeNO in bronchiolitis obliterans}

Bronchiolitis obliterans (BO) is almost secondary to lung transplantation in adults [153], while the most common form in children is post-infectious BO [154]. FeNO levels are increased in adult $\mathrm{BO}$ that occurs after lung transplantation $[155,156]$, and correlate with NOS2 expression in the bronchial epithelium and with the percentage of BAL neutrophils [157-161]. No pediatric studies evaluating the role of FeNO in children with $\mathrm{BO}$ after lung transplantation have been published. The availability of a non-invasive biomarker that can identify patients in whom more invasive diagnostic procedures such as BAL or lung biopsies are justified (or can be avoided) would be very helpful to improve the management of children with $\mathrm{BO}$.

\section{Conclusions}

NO seems to significantly influence a variety of physiological and pathophysiological processes in the upper and lower airways. FeNO measurement is easy to perform, and seems reproducible also in the preschool age. The availability of hand-held devices will hopefully increase its use in the pediatric practice. Combined with symptoms registration and lung function measurements, FeNO provides additional information that can be applied to support the diagnosis of asthma and to optimize the management of affected children. Moreover, recent studies suggest that FeNO is helpful in predicting both onset and exacerbations of asthma. Since most studies have been performed in adult populations, more research is needed to confirm the usefulness of NO measurement in the diagnosis and management of pediatric chronic airway disorders different from asthma.

\section{Abbreviations \\ NO: Nitric oxide; NOS: NO synthase; FeNO: Fractional exhaled nitric oxide; ICS: Inhaled corticosteroids; RSV: Respiratory syncytial virus; CAP: Community acquired pneumonia; CF: Cystic fibrosis, PCD, Primary ciliary dyskinesia; HRCT: High-resolution computed tomography; DLD: Diffuse lung disease; BAL: Bronchoalveolar lavage; BO: Bronchiolitis obliterans.}

\section{Competing interests}

All authors declare that they have no significant competing financial, professional or personal interests that might have influenced the performance or presentation of the work described in this manuscript.

\section{Authors' contributions}

AM has been involved in drafting the manuscript; CC has been involved in revising the manuscript critically for important intellectual content; MV has made substantial contributions to acquisition, analysis and interpretation of data; CP has made substantial contributions to acquisition, analysis and interpretation of data; SM has been involved in drafting the manuscript; MM has been involved in drafting the manuscript; FSp has made substantial contributions to acquisition, analysis and interpretation of data; FS has been involved in drafting the manuscript, revising it critically for important intellectual content and has given final approval of the version to be published. All authors read and approved the final manuscript.

\section{Author details}

${ }^{1}$ Department of Pediatrics, Federico II University, Via Sergio Pansini, 580131 Naples, Italy. ${ }^{2}$ Department of Pediatrics, University Hospital of Parma, Parma, Italy.

Received: 11 October 2012 Accepted: 19 December 2012

Published: 31 December 2012

\section{References}

1. Moncada S, Higgs A: The L-arginine-nitric oxide pathway. N Engl J Med 1993, 329:2002-2012.

2. Maniscalco M, Sofia M, Pelaia G: Nitric oxide in upper airways inflammatory diseases. Inflamm Res 2007, 56:58-69.

3. Kharitonov SA, Barnes PJ: Exhaled markers of pulmonary disease. Am J Respir Crit Care Med 2001, 163:1693-1722.

4. Lundberg JO, Farkas-Szallasi T, Weitzberg E, Rinder J, Lidholm J, Anggåard A, Hökfelt T, Lundberg JM, Alving K: High nitric oxide production in human paranasal sinuses. Nat Med 1995, 1:370-373.

5. American Thoracic Society; European Respiratory Society: ATS/ERS recommendations for standardized procedures for the online and offline measurement of exhaled lower respiratory nitric oxide and nasal nitric oxide, 2005. Am J Respir Crit Care Med 2005, 171:912-930.

6. Baraldi E, Carraro S: Exhaled NO and breath condensate. Paediatr Respir Rev 2006, 7(Suppl 1):20-22.

7. Montella S, Alving K, Maniscalco M, Sofia M, De Stefano S, Raia V, Santamaria F: Measurement of nasal nitric oxide by hand-held and stationary devices. Eur J Clin Invest 2011, 41:1063-1070.

8. Santamaria F, De Stefano S, Montella S, Barbarano F, lacotucci P, Ciccarelli R, Sofia M, Maniscalco M: Nasal nitric oxide assessment in primary ciliary dyskinesia using aspiration, exhalation, and humming. Med Sci Monit 2008, 14:80-85.

9. Santamaria F, Montella S, De Stefano S, Sperlì F, Barbarano F, Spadaro R, Franzese A: Asthma, atopy, and airway inflammation in obese children. J Allergy Clin Immunol 2007, 120:965-967.

10. Corradi M, Zinelli C, Caffarelli C: Exhaled breath biomarkers in asthmatic children. Inflamm Allergy Drug Targets 2007, 6:150-159.

11. Baraldi E, de Jongste JC, European Respiratory Society/American Thoracic Society (ERS/ATS) Task Force: Measurement of exhaled nitric oxide in children, 2001. Eur Respir J 2002, 20:223-237.

12. Buchvald F, Bisgaard $\mathrm{H}$ : FeNO measured at fixed exhalation flow rate during controlled tidal breathing in children from the age of $2 \mathrm{yr}$. Am J Respir Crit Care Med 2001, 163:699-704

13. Borrill Z, Clough D, Truman N, Morris J, Langley S, Singh D: A comparison of exhaled nitric oxide measurements performed using three different analysers. Respir Med 2006, 100:1392-1396.

14. Alving $K$, Janson C, Nordvall L: Performance of a new hand-held device for exhaled nitric oxide measurement in adults and children. Respir Res 2006, 7:67.

15. Boot JD, de Ridder $L$, de Kam ML, Calderon C, Mascelli MA, Diamant Z: Comparison of exhaled nitric oxide measurements between NIOX MINO electrochemical and Ecomedics chemiluminescence analyzer. Respir Med 2008, 102:1667-1671.

16. Menzies D, Nair A, Lipworth BJ: Portable exhaled nitric oxide measurement: Comparison with the "gold standard" technique. Chest 2007, 131:410-414

17. Korn S, Telke I, Kornmann O, Buhl R: Measurement of exhaled nitric oxide: comparison of different analysers. Respirology 2010, 15:1203-1208.

18. Baraldi E, Azzolin NM, Cracco A, Zacchello F: Reference values of exhaled nitric oxide for healthy children 6-15 years old. Pediatr Pulmonol 1999, 27:54-58.

19. Buchvald F, Baraldi E, Carraro S, Gaston B, De Jongste J, Pijnenburg MW, Silkoff $P E$, Bisgaard $\mathrm{H}$ : Measurements of exhaled nitric oxide in healthy subjects age 4 to 17 years. J Allergy Clin Immunol 2005, 115:1130-1136.

20. Kovesi T, Kulka R, Dales R: Exhaled nitric oxide concentration is affected by age, height, and race in healthy 9- to 12-year-old children. Chest 2008, 133:169-175.

21. Wong GW, Liu EK, Leung TF, Yung E, Ko FW, Hui DS, Fok TF, Lai CK: High levels and gender difference of exhaled nitric oxide in Chinese schoolchildren. Clin Exp Allergy 2005, 35:889-893. 
22. Malmberg LP, Petäys T, Haahtela T, Laatikainen $T$, Jousilahti $P$, Vartiainen $E$, Mäkelä MJ: Exhaled nitric oxide in healthy nonatopic school-age children: determinants and height-adjusted reference values. Pediatr Pulmonol 2006, 41:635-642.

23. Yao TC, Lee Wl, Ou LS, Chen LC, Yeh KW, Huang JL, PATCH Study Group: Reference values of exhaled nitric oxide in healthy Asian children aged 5 to 18 years. Eur Respir J 2012, 39:378-384.

24. Dötsch J, Demirakça S, Terbrack HG, Hüls G, Rascher W, Kühl PG: Airway nitric oxide in asthmatic children and patients with cystic fibrosis. Eur Respir J 1996, 9:2537-2540.

25. Silvestri M, Spallarossa D, Frangova Yourukova V, Battistini E, Fregonese B, Rossi GA: Orally exhaled nitric oxide levels are related to the degree of blood eosinophilia in atopic children with mild-intermittent asthma. Eur Respir J 1999, 13:321-326

26. Franklin PJ, Taplin R, Stick SM: A community study of exhaled nitric oxide in healthy children. Am J Respir Crit Care Med 1999, 159:69-73.

27. Latzin P, Beck J, Griese M: Exhaled nitric oxide in healthy children: variability and a lack of correlation with atopy. Pediatr Allergy Immunol 2002, 13:37-46.

28. Jouaville LF, Annesi-Maesano I, Nguyen LT, Bocage AS, Bedu M, Caillaud D: Interrelationships among asthma, atopy, rhinitis and exhaled nitric oxide in a population-based sample of children. Clin Exp Allergy 2003, 33:1506-1511.

29. Grob NM, Dweik RA: Exhaled nitric oxide in asthma. From diagnosis, to monitoring, to screening: are we there yet? Chest 2008, 133:837-839.

30. Olin AC, Bake B, Torén $\mathrm{K}$ : Fraction of exhaled nitric oxide at $50 \mathrm{~mL} / \mathrm{s}$ : reference values for adult lifelong never-smokers. Chest 2007, 131:1852-1856.

31. Travers J, Marsh S, Aldington S, Williams M, Shirtcliffe P, Pritchard A, Weatherall M, Beasley R: Reference ranges for exhaled nitric oxide derived from a random community survey of adults. Am J Respir Crit Care Med 2007, 176:238-242

32. Taylor DR, Mandhane P, Greene JM, Hancox RJ, Filsell S, McLachlan CR, Williamson AJ, Cowan JO, Smith AD, Sears MR: Factors affecting exhaled nitric oxide measurements: the effect of sex. Respir Res 2007, 8:82

33. Global Strategy for Asthma Management and Prevention. Global Initiative for Asthma (GINA). http://www.ginasthma.org/.

34. British Thoracic Society Scottish Intercollegiate Guidelines Network: British Guideline on the Management of Asthma. Thorax 2008, 63(Suppl 4):1-121.

35. Chedevergne $F$, Le Bourgeois M, de Blic J, Scheinmann P: The role of inflammation in childhood asthma. Arch Dis Child 2000, 82(Suppl 2):6-9.

36. Caffarelli C, Calcinai E, Rinaldi L, Povesi Dascola C, Terracciano L, Corradi M: Hydrogen peroxide in exhaled breath condensate in asthmatic children during acute exacerbation and after treatment. Respiration 2012, 84:291-298.

37. Alving K, Weitzberg E, Lundberg JM: Increased amount of nitric oxide in exhaled air of asthmatics. Eur Respir J 1993, 6:1368-1370.

38. Kharitonov SA, Yates D, Robbins RA, Logan-Sinclair R, Shinebourne EA, Barnes PJ: Increased nitric oxide in exhaled air of asthmatic patients. Lancet 1994, 343:133-135.

39. Hamid Q, Springall DR, Riveros-Moreno V, Chanez P, Howarth P, Redington A, Bousquet J, Godard P, Holgate S, Polak JM: Induction of nitric oxide synthase in asthma. Lancet 1993, 342:1510-1513.

40. Baraldi E, Azzolin NM, Zanconato S, Dario C, Zacchello F: Corticosteroids decrease exhaled nitric oxide in children with acute asthma. J Pediatr 1997, 131:381-385.

41. Byrnes CA, Dinarevic S, Shinebourne EA, Barnes PJ, Bush A: Exhaled nitric oxide measurements in normal and asthmatic children. Pediatr Pulmono 1997, 24:312-318.

42. Lundberg JO, Nordvall SL, Weitzberg E, Kollberg H, Alving K: Exhaled nitric oxide in paediatric asthma and cystic fibrosis. Arch Dis Child 1996, 75:323-326

43. Warke TJ, Fitch PS, Brown V, Taylor R, Lyons JD, Ennis M, Shields MD: Exhaled nitric oxide correlates with airway eosinophils in childhood asthma. Thorax 2002, 57:383-387.

44. Payne DN, Adcock IM, Wilson NM, Oates T, Scallan M, Bush A: Relationship between exhaled nitric oxide and mucosal eosinophilic inflammation in children with difficult asthma, after treatment with oral prednisolone. Am J Respir Crit Care Med 2001, 164:1376-1381.

45. Lim S, Jatakanon A, Meah S, Oates T, Chung KF, Barnes PJ: Relationship between exhaled nitric oxide and mucosal eosinophilic inflammation in mild to moderately severe asthma. Thorax 2000, 55:184-188.
46. Silvestri M, Sabatini F, Sale R, Defilippi AC, Fregonese L, Battistini E, Biraghi MG, Rossi GA: Correlations between exhaled nitric oxide levels, blood eosinophilia, and airway obstruction reversibility in childhood asthma are detectable only in atopic individuals. Pediatr Pulmonol 2003, 35:358-363.

47. Lex C, Ferreira F, Zacharasiewicz A, Nicholson AG, Haslam PL, Wilson NM, Hansel TT, Payne DN, Bush A: Airway eosinophilia in children with severe asthma: predictive values of noninvasive tests. Am J Respir Crit Care Med 2006, 174:1286-1291.

48. Wenzel SE: Asthma: defining of the persistent adult phenotypes. Lancet 2006, 368:804-813.

49. Brussee JE, Smit HA, Kerkhof M, Koopman LP, Wijga AH, Postma DS, Gerritsen J, Grobbee DE, Brunekreef B, de Jongste JC: Exhaled nitric oxide in 4-year-old children: relationship with asthma and atopy. Eur Respir J 2005, 25:455-461.

50. Dupont LJ, Demedts MG, Verleden GM: Prospective evaluation of the validity of exhaled nitric oxide for the diagnosis of asthma. Chest 2003, 123:751-756.

51. Sivan Y, Gadish T, Fireman E, Soferman R: The use of exhaled nitric oxide in the diagnosis of asthma in school children. J Pediatr 2009, 155:211-216.

52. Sachs-Olsen C, Lødrup Carlsen KC, Mowinckel P, Håland G, Devulapalli CS, Munthe-Kaas MC, Carlsen KH: Diagnostic value of exhaled nitric oxide in childhood asthma and allergy. Pediatr Allergy Immunol 2010, 21(1 Pt 2):213-221.

53. Pérez Tarazona S, Martínez Camacho RM, Alfonso Diego J, Escolano Serrano S, Talens Gandía J: Diagnostic value of exhaled nitric oxide measurement in mild asthma. An Pediatr (Barc) 2011, 75:320-328.

54. Yao TC, Ou LS, Lee WI, Yeh KW, Chen LC, Huang JL, PATCH study group: Exhaled nitric oxide discriminates children with and without allergic sensitization in a population-based study. Clin Exp Allergy 2011, 41:556-564.

55. Cordeiro D, Rudolphus A, Snoey E, Braunstahl GJ: Utility of nitric oxide for the diagnosis of asthma in an allergy clinic population. Allergy Asthma Proc 2011, 32:119-126.

56. Woo SI, Lee JH, Kim H, Kang JW, Sun YH, Hahn YS: Utility of fractional exhaled nitric oxide ( $(\mathrm{E}) \mathrm{NO})$ measurements in diagnosing asthma. Respir Med 2012, 106:1103-1109.

57. Berkman N, Avital A, Breuer R, Bardach E, Springer C, Godfrey S: Exhaled nitric oxide in the diagnosis of asthma: comparison with bronchial provocation tests. Thorax 2005, 60:383-388.

58. Malmberg LP, Pelkonen AS, Haahtela T, Turpeinen M: Exhaled nitric oxide rather than lung function distinguishes preschool children with probable asthma. Thorax 2003, 58:494-499.

59. Frank TL, Adisesh A, Pickering AC, Morrison JF, Wright T, Francis $H$, Fletcher A, Frank PI, Hannaford P: Relationship between exhaled nitric oxide and childhood asthma. Am J Respir Crit Care Med 1998, 158:1032-1036.

60. Lúdvíksdóttir D, Janson C, Högman M, Hedenström H, Björnsson E, Boman G: Exhaled nitric oxide and its relationship to airway responsiveness and atopy in asthma. BHR-Study Group. Respir Med 1999, 93:552-556.

61. Gratziou C, Lignos M, Dassiou M, Roussos C: Influence of atopy on exhaled nitric oxide in patients with stable asthma and rhinitis. Eur Respir J 1999, 14:897-901.

62. Silvestri M, Sabatini F, Spallarossa D, Fregonese L, Battistini E, Biraghi MG, Rossi GA: Exhaled nitric oxide levels in non-allergic and allergic mono- or polysensitised children with asthma. Thorax 2001, 56:857-862.

63. Linn WS, Rappaport EB, Berhane KT, Bastain TM, Avol EL, Gilliland FD: Exhaled nitric oxide in a population-based study of southern California schoolchildren. Respir Res 2009, 10:28.

64. Vahlkvist S, Sinding M, Skamstrup K, Bisgaard H: Daily home measurements of exhaled nitric oxide in asthmatic children during natural birch pollen exposure. J Allergy Clin Immunol 2006, 117:1272-1276.

65. Zinelli C, Caffarelli C, Strid J, Jaffe A, Atherton DJ: Measurement of nitric oxide and 8-isoprostane in exhaled breath of children with atopic eczema. Clin Exp Dermatol 2009, 34:607-612.

66. Tantisira KG, Weiss ST: Complex interactions in complex traits: obesity and asthma. Thorax 2001, 56(Suppl 2):64-73.

67. Santamaria F, Montella S, Pietrobelli A: Obesity and pulmonary disease: unanswered questions. Obes Rev 2012, 13:822-833.

68. Santamaria F, Montella S, Greco L, Valerio G, Franzese A, Maniscalco M, Fiorentino G, Peroni D, Pietrobelli A, De Stefano S, Sperli F, Boner AL: Obesity duration is associated to pulmonary function impairment in obese subjects. Obesity (Silver Spring) 2011, 19:1623-1628. 
69. Santamaria F, Montella S, De Stefano S, Sperli F, Barbarano F, Valerio G: Relationship between exhaled nitric oxide and body mass index in children and adolescents. J Allergy Clin Immunol 2005, 116:1163-1164.

70. Berg CM, Thelle DS, Rosengren A, Lissner L, Torén K, Olin AC: Decreased fraction of exhaled nitric oxide in obese subjects with asthma symptoms: data from the population study INTERGENE/ADONIX. Chest 2011, 139:1109-1116.

71. Leung TF, Li CY, Lam CW, Au CS, Yung E, Chan IH, Wong GW, Fok TF: The relation between obesity and asthmatic airway inflammation. Pediatr Allergy Immunol 2004, 15:344-350.

72. Peroni DG, Pietrobelli A, Boner AL: Asthma and obesity in childhood: on the road ahead. Int J Obes (Lond) 2010, 34:599-605.

73. Smith AD, Cowan JO, Filsell S, McLachlan C, Monti-Sheehan G, Jackson P Taylor DR: Diagnosing asthma: comparisons between exhaled nitric oxide measurements and conventional tests. Am J Respir Crit Care Med 2004, 169:473-478

74. Ciprandi G, Tosca MA, Capasso M: Exhaled nitric oxide in children with allergic rhinitis and/or asthma: a relationship with bronchial hyperreactivity. J Asthma 2010, 47:1142-1147.

75. Steerenberg PA, Janssen NA, de Meer G, Fischer PH, Nierkens S, van Loveren $H$, Opperhuizen A, Brunekreef B, van Amsterdam JG: Relationship between exhaled NO, respiratory symptoms, lung function, bronchial hyperresponsiveness, and blood eosinophilia in school children. Thorax 2003, 58:242-245.

76. Jatakanon A, Lim S, Kharitonov SA, Chung KF, Barnes PJ: Correlation between exhaled nitric oxide, sputum eosinophils, and methacholine responsiveness in patients with mild asthma. Thorax 1998, 53:91-95.

77. Strunk RC, Szefler SJ, Phillips BR, Zeiger RS, Chinchilli VM, Larsen G, Hodgdon K, Morgan W, Sorkness CA, Lemanske RF Jr, Childhood Asthma Research and Education Network of the National Heart, Lung, and Blood Institute: Relationship of exhaled nitric oxide to clinical and inflammatory markers of persistent asthma in children. J Allergy Clin Immunol 2003, 112:883-892.

78. Grzelewski T, Grzelewska A, Majak P, Stelmach W, Kowalska A, Stelmach R, Janas A, Stelmach I: Fractional exhaled nitric oxide (FeNO) may predict exercise-induced bronchoconstriction (EIB) in schoolchildren with atopic asthma. Nitric Oxide 2012, 27:82-87.

79. Dweik RA, Boggs PB, Erzurum SC, Irvin CG, Leigh MW, Lundberg JO, Olin AC, Plummer AL, Taylor DR, American Thoracic Society Committee on Interpretation of Exhaled Nitric Oxide Levels (FENO) for Clinical Applications: An official ATS clinical practice guideline: interpretation of exhaled nitric oxide levels (FENO) for clinical applications. Am J Respir Crit Care Med 2011, 184:602-615.

80. Narang I, Ersu R, Wilson NM, Bush A: Nitric oxide in chronic airway inflammation in children: diagnostic use and pathophysiological significance. Thorax 2002, 57:586-589

81. Warke TJ, Mairs V, Fitch PS, McGovern V, Ennis M, Shields MD: Exhaled nitric oxide in relation to the clinical features of childhood asthma. J Asthma 2004, 41:751-757.

82. Bastain TM, Islam T, Berhane KT, McConnell RS, Rappaport EB, Salam MT, Linn WS, Avol EL, Zhang Y, Gilliland FD: Exhaled nitric oxide, susceptibility and new-onset asthma in the Children's Health Study. Eur Respir J 2011, 37:523-531.

83. Malinovschi A, Alving K, Kalm-Stephens P, Janson C, Nordvall L: Increased exhaled nitric oxide predicts new-onset rhinitis and persistent rhinitis in adolescents without allergic symptoms. Clin Exp Allergy 2012, 42:433-440.

84. Siegle JS, Hansbro N, Dong C, Angkasekwinai P, Foster PS, Kumar RK Blocking induction of T helper type 2 responses prevents development of disease in a model of childhood asthma. Clin Exp Immunol 2011, 165:19-28.

85. Franklin PJ, Turner SW, Le Souëf PN, Stick SM: Exhaled nitric oxide and asthma: complex interactions between atopy, airway responsiveness, and symptoms in a community population of children. Thorax 2003, 58:1048-1052.

86. Stirling RG, Kharitonov SA, Campbell D, Robinson DS, Durham SR, Chung KF, Barnes PJ: Increase in exhaled nitric oxide levels in patients with difficult asthma and correlation with symptoms and disease severity despite treatment with oral and inhaled corticosteroids.Asthma and Allergy Group. Thorax 1998, 53:1030-1034.

87. Artlich A, Busch T, Lewandowski K, Jonas S, Gortner L, Falke KJ: Childhood asthma: exhaled nitric oxide in relation to clinical symptoms. Eur Respir 1999, 13:1396-1401.
88. Roberts G, Hurley C, Bush A, Lack G: Longitudinal study of grass pollen exposure, symptoms, and exhaled nitric oxide in childhood seasonal allergic asthma. Thorax 2004, 59:752-756.

89. Nordvall SL, Janson C, Kalm-Stephens P, Foucard T, Torén K, Alving K: Exhaled nitric oxide in a population-based study of asthma and allergy in schoolchildren. Allergy 2005, 60:469-475.

90. Stern G, de Jongste J, van der Valk R, Baraldi E, Carraro S, Thamrin C, Frey U: Fluctuation phenotyping based on daily fraction of exhaled nitric oxide values in asthmatic children. J Allergy Clin Immunol 2011, 128:293-300.

91. Debley JS, Stamey DC, Cochrane ES, Gama KL, Redding GJ: Exhaled nitric oxide, lung function, and exacerbations in wheezy infants and toddlers. J Allergy Clin Immunol 2010, 125:1228-1234.

92. Green RJ, Klein M, Becker P, Halkas A, Lewis H, Kitchin O, Moodley T, Masekela R: Disagreement between common measures of asthma control in children. Chest 2012, in press.

93. Waibel $\mathrm{V}$, Ulmer H, Horak E: Assessing asthma control: symptom scores, GINA levels of asthma control, lung function, and exhaled nitric oxide. Pediatr Pulmonol 2012, 47:113-118.

94. Rosias PP, Dompeling E, Dentener MA, Pennings HJ, Hendriks HJ, Van lersel MP, Jöbsis Q: Childhood asthma: exhaled markers of airway inflammation, asthma control score, and lung function tests. Pediatr Pulmonol 2004, 38:107-114.

95. Colon-Semidey AJ, Marshik P, Crowley M, Katz R, Kelly HW: Correlation between reversibility of airway obstruction and exhaled nitric oxide levels in children with stable bronchial asthma. Pediatr Pulmonol 2000, 30:385-392.

96. Hunt J, Gaston B: Airway nitrogen oxide measurements in asthma and other pediatric respiratory diseases. J Pediatr 2000, 137:14-20.

97. Piacentini GL, Bodini A, Costella S, Suzuki Y, Zerman L, Peterson CG, Boner AL: Exhaled nitric oxide, serum ECP and airway responsiveness in mild asthmatic children. Eur Respir J 2000, 15:839-843.

98. del Giudice MM, Brunese FP, Piacentini GL, Pedullà M, Capristo C, Decimo F, Capristo AF: Fractional exhaled nitric oxide (FENO), lung function and airway hyperresponsiveness in naïve atopic asthmatic children. J Asthma 2004, 41:759-765.

99. Zietkowski Z, Bodzenta-Lukaszyk A, Tomasiak MM, Szymanski W, Skiepko R: Effect of ciclesonide and fluticasone on exhaled nitric oxide in patients with mild allergic asthma. Respir Med 2006, 100:1651-1656.

100. van Rensen EL, Straathof KC, Veselic-Charvat MA, Zwinderman AH, Bel EH, Sterk PJ: Effect of inhaled steroids on airway hyperresponsiveness, sputum eosinophils, and exhaled nitric oxide levels in patients with asthma. Thorax 1999, 54:403-408.

101. Taylor DR, Pijnenburg MW, Smith AD, De Jongste JC: Exhaled nitric oxide measurements: clinical application and interpretation. Thorax 2006, 61:817-827.

102. de Jongste JC, Carraro S, Hop WC, CHARISM Study Group, Baraldi E: Daily telemonitoring of exhaled nitric oxide and symptoms in the treatment of childhood asthma. Am J Respir Crit Care Med 2009, 179:93-97.

103. Pijnenburg MW, Bakker EM, Hop WC, De Jongste JC: Titrating steroids on exhaled nitric oxide in children with asthma: a randomized controlled trial. Am J Respir Crit Care Med 2005, 172:831-836.

104. Fritsch M, Uxa S, Horak F Jr, Putschoegl B, Dehlink E, Szepfalusi Z, Frischer T: Exhaled nitric oxide in the management of childhood asthma: a prospective 6-months study. Pediatr Pulmonol 2006, 41:855-862.

105. Szefler SJ, Mitchell H, Sorkness CA, Gergen PJ, O'Connor GT, Morgan WJ, Kattan M, Pongracic JA, Teach SJ, Bloomberg GR, Eggleston PA, Gruchalla RS, Kercsmar CM, Liu AH, Wildfire JJ, Curry MD, Busse WW: Management of asthma based on exhaled nitric oxide in addition to guideline-based treatment for inner-city adolescents and young adults: a randomised controlled trial. Lancet 2008, 372:1065-1072.

106. Petsky HL, Cates CJ, Lasserson TJ, Li AM, Turner C, Kynaston JA, Chang AB: A systematic review and meta-analysis: tailoring asthma treatment on eosinophilic markers (exhaled nitric oxide or sputum eosinophils). Thorax 2012, 67:199-208.

107. Pijnenburg MW, Floor SE, Hop WC, De Jongste JC: Daily ambulatory exhaled nitric oxide measurements in asthma. Pediatr Allergy Immunol 2006, 17:189-193.

108. Pijnenburg MW, Bakker EM, Lever S, Hop WC, De Jongste JC: High fractional concentration of nitric oxide in exhaled air despite steroid treatment in asthmatic children. Clin Exp Allergy 2005, 35:920-925. 
109. Gelb AF, Taylor CF, Shinar CM, Gutierrez CA, Zamel N: Effect of fluticasone $250 \mathrm{microg} / \mathrm{salmeterol} 50$ microg and montelukast on exhaled nitric oxide in asthmatic patients. Can Respir J 2008, 15:193-198

110. Buchvald F, Eiberg $H$, Bisgaard $H$ : Heterogeneity of FeNO response to inhaled steroid in asthmatic children. Clin Exp Allergy 2003 33:1735-1740.

111. Michils A, Baldassarre S, Van Muylem A: Exhaled nitric oxide and asthma control: a longitudinal study in unselected patients. Eur Respir J 2008, 31:539-546.

112. Pifferi M, Bush A, Pioggia G, Di Cicco M, Chinellato I, Bodini A, Macchia P, Boner AL: Monitoring asthma control in children with allergies by soft computing of lung function and exhaled nitric oxide. Chest 2011, 139:319-327.

113. van der Valk RJ, Baraldi E, Stern G, Frey U, de Jongste JC: Daily exhaled nitric oxide measurements and asthma exacerbations in children. Allergy 2012, 67:265-271

114. Bisgaard H, Loland L, Oj JA: NO in exhaled air of asthmatic children is reduced by the leukotriene receptor antagonist montelukast. Am J Respir Crit Care Med 1999, 160:1227-1231.

115. Ghiro L, Zanconato S, Rampon O, Piovan V, Pasquale MF, Baraldi E: Effect of montelukast added to inhaled corticosteroids on fractional exhaled nitric oxide in asthmatic children. Eur Respir J 2002, 20:630-634.

116. Straub DA, Minocchieri S, Moeller A, Hamacher J, Wildhaber JH: The effect of montelukast on exhaled nitric oxide and lung function in asthmatic children 2 to 5 years old. Chest 2005, 127:509-514.

117. Silkoff PE, Romero FA, Gupta N, Townley RG, Milgrom H: Exhaled nitric oxide in children with asthma receiving Xolair (omalizumab), a monoclonal anti-immunoglobulin E antibody. Pediatrics 2004, 113:308-312.

118. Hoffman SJ, Laham FR, Polack FP: Mechanisms of illness during respiratory syncytial virus infection: the lungs, the virus and the immune response. Microb Infect 2004, 6:767-772

119. Stark JM, Khan AM, Chiappetta CL, Xue H, Alcorn JL, Colasurdo GN: Immune and functional role of nitric oxide in a mouse model of respiratory syncytial virus infection. J Infect Dis 2005, 191:387-395.

120. Song W, Liu G, Bosworth CA, Walker JR, Megaw GA, Lazrak A, Abraham E, Sullender WM, Matalon S: Respiratory syncytial virus inhibits lung epithelial $\mathrm{Na}+$ channels by up-regulating inducible nitric-oxide synthase. J Biol Chem 2009, 284:7294-7306.

121. Tsutsumi H, Takeuchi R, Ohsaki M, Seki K, Chiba S: Respiratory syncytial virus infection of human respiratory epithelial cells enhances inducible nitric oxide synthase gene expression. J Leukoc Biol 1999, 66:99-104.

122. Kao YJ, Piedra PA, Larsen GL, Colasurdo GN: Induction and regulation of nitric oxide synthase in airway epithelial cells by respiratory syncytial virus. Am J Respir Crit Care Med 2001, 163:532-539.

123. Gadish T, Soferman R, Merimovitch T, Fireman E, Sivan Y: Exhaled nitric oxide in acute respiratory syncytial virus bronchiolitis. Arch Pediatr Adolesc Med 2010, 164:727-731

124. Kovesi T, Dales R: Exhaled nitric oxide and respiratory symptoms in a community sample of school aged children. Pediatr Pulmonol 2008, 43:1198-1205.

125. Carraro S, Andreola B, Alinovi R, Corradi M, Freo L, Da Dalt L, Baraldi E: Exhaled leukotriene B4 in children with community acquired pneumonia. Pediatr Pulmonol 2008, 43:982-986.

126. Pasteur MC, Bilton D, Hill AT, British Thoracic Society Bronchiectasis non-CF Guideline Group: British Thoracic Society guideline for non-CF bronchiectasis. Thorax 2010, 65(1):1-58.

127. Santamaria F, Montella S, Tiddens HA, Guidi G, Casotti V, Maglione M, de Jong PA: Structural and functional lung disease in primary ciliary dyskinesia. Chest 2008, 134:351-357.

128. Santamaria F, Montella S, Pifferi M, Ragazzo V, De Stefano S, De Paulis N, Maglione M, Boner AL: A descriptive study of non-cystic fibrosis bronchiectasis in a pediatric population from central and southern Italy. Respiration 2009, 77:160-165.

129. Patel IS, Vlahos I, Wilkinson TM, Lloyd-Owen SJ, Donaldson GC, Wilks M, Reznek RH, Wedzicha JA: Bronchiectasis, exacerbation indices, and inflammation in chronic obstructive pulmonary disease. Am J Respir Crit Care Med 2004, 170:400-407.

130. Chang AB, Masel JP, Masters B: Post-infectious bronchiolitis obliterans: clinical, radiological and pulmonary function sequelae. Pediatr Radiol 1998, 28:23-29.
131. Chang $A B$, Bilton $D$ : Exacerbations in cystic fibrosis: 4-Non-cystic fibrosis bronchiectasis. Thorax 2008, 63:269-276.

132. Santamaria F, Montella S, Camera L, Palumbo C, Greco L, Boner AL: Lung structure abnormalities, but normal lung function in pediatric bronchiectasis. Chest 2006, 130:480-486.

133. Montella S, Santamaria F, Salvatore M, Pignata C, Maglione M, lacotucci P, Mollica C: Assessment of chest high-field magnetic resonance imaging in children and young adults with non-cystic fibrosis chronic lung disease: comparison to high-resolution computed tomography and correlation with pulmonary function. Invest Radiol 2009, 44:532-538.

134. Montella S, Maglione M, Bruzzese D, Mollica C, Pignata C, Aloj G, Manna A, Esposito A, Mirra V, Santamaria F: Magnetic resonance imaging is an accurate and reliable method to evaluate non-cystic fibrosis paediatric lung disease. Respirology 2012, 17:87-91.

135. Wilson CB, Jones PW, O'Leary CJ, Hansell DM, Cole PJ, Wilson R: Effect of sputum bacteriology on the quality of life of patients with bronchiectasis. Eur Respir J 1997, 10:1754-1760.

136. Shoemark A, Devaraj A, Meister M, Ozerovitch L, Hansell DM, Wilson R: Elevated peripheral airway nitric oxide in bronchiectasis reflects disease severity. Respir Med 2011, 105:885-891.

137. Kharitonov SA, Wells AU, O'Connor BJ, Cole PJ, Hansell DM, Logan-Sinclair RB, Barnes PJ: Elevated levels of exhaled nitric oxide in bronchiectasis. Am J Respir Crit Care Med 1995, 151:1889-1893.

138. Horváth I, Loukides S, Wodehouse T, Csiszér E, Cole PJ, Kharitonov SA, Barnes PJ: Comparison of exhaled and nasal nitric oxide and exhaled carbon monoxide levels in bronchiectatic patients with and without primary ciliary dyskinesia. Thorax 2003, 58:68-72.

139. Ho LP, Innes JA, Greening AP: Exhaled nitric oxide is not elevated in the inflammatory airways diseases of cystic fibrosis and bronchiectasis. Eur Respir J 1998, 12:1290-1294.

140. Tsang KW, Leung R, Fung PC, Chan SL, Tipoe GL, Ooi GC, Lam WK: Exhaled and sputum nitric oxide in bronchiectasis: correlation with clinical parameters. Chest 2002, 121:88-94.

141. Zihlif N, Paraskakis E, Lex C, Van de Pohl LA, Bush A: Correlation between cough frequency and airway inflammation in children with primary ciliary dyskinesia. Pediatr Pulmonol 2005, 39:551-557.

142. Robroeks CM, Rosias PP, van Vliet D, Jöbsis Q, Yntema JB, Brackel HJ Damoiseaux JG, den Hartog GM, Wodzig WK, Dompeling E: Biomarkers in exhaled breath condensate indicate presence and severity of cystic fibrosis in children. Pediatr Allergy Immunol 2008, 19:652-659.

143. Grasemann H, Michler E, Wallot M, Ratjen F: Decreased concentration of exhaled nitric oxide (NO) in patients with cystic fibrosis. Pediatr Pulmonol 1997, 24:173-177.

144. Tsoukias NM, George SC: A two-compartment model of pulmonary nitric oxide exchange dynamics. J Appl Physio/ 1998, 85:653-666.

145. Keen C, Gustafsson P, Lindblad A, Wennergren G, Olin AC: Low levels of exhaled nitric oxide are associated with impaired lung function in cystic fibrosis. Pediatr Pulmonol 2010, 45:241-248.

146. Suri R, Paraskakis E, Bush A: Alveolar, but not bronchial nitric oxide production is elevated in cystic fibrosis. Pediatr Pulmonol 2007, 42:1215-1221.

147. Paraskakis E, Zihlif N, Bush A: Nitric oxide production in PCD: possible evidence for differential nitric oxide synthase function. Pediatr Pulmonol 2007, 42:876-880.

148. Vece TJ, Fan LL: Diagnosis and management of diffuse lung disease in children. Paediatr Respir Rev 2011, 12:238-242

149. Doan ML, Guillerman RP, Dishop MK, Nogee LM, Langston C, Mallory GB, Sockrider MM, Fan LL: Clinical, radiological and pathological features of ABCA3 mutations in children. Thorax 2008, 63:366-373.

150. Malerba M, Radaeli A, Ragnoli B, Airo' P, Corradi M, Ponticiello A, Zambruni A, Grassi V: Exhaled nitric oxide levels in systemic sclerosis with and without pulmonary involvement. Chest 2007, 132:575-580.

151. Sandrini A, Johnson AR, Thomas PS, Yates DH: Fractional exhaled nitric oxide concentration is increased in asbestosis and pleural plaques. Respirology 2006, 11:325-329.

152. Wilsher ML, Fergusson W, Milne D, Wells AU: Exhaled nitric oxide in sarcoidosis. Thorax 2005, 60:967-970.

153. Estenne M, Hertz Ml: Bronchiolitis obliterans after human lung transplantation. Am J Respir Crit Care Med 2002, 166:440-444.

154. Zhang L, Irion K, Kozakewich H, Reid L, Camargo JJ, da Silva Porto N, Silva FA Ae: Clinical course of postinfectious bronchiolitis obliterans. Pediatr Pulmonol 2000, 29:341-350. 
155. Fisher AJ, Gabbay E, Small T, Doig S, Dark JH, Corris PA: Cross sectional study of exhaled nitric oxide levels following lung transplantation. Thorax 1998, 53:454-458.

156. Verleden GM, Dupont L, Lamont J, Buyse B, Delcroix M, Van Raemdonck D, Lerut T, Vanhaecke J, Demedts MG: Is there a role for measuring exhaled nitric oxide in lung transplant recipients with chronic rejection? $J$ Heart Lung Transplant 1998, 17:231-232.

157. Neurohr C, Huppmann P, Leuschner S, von Wulffen W, Meis T, Leuchte $H$, Ihle F, Zimmermann G, Baezner C, Hatz R, Winter H, Frey L, Ueberfuhr $P$, Bittmann I, Behr J, Munich Lung Transplant Group: Usefulness of exhaled nitric oxide to guide risk stratification for bronchiolitis obliterans syndrome after lung transplantation. Am J Transplant 2011, 11:129-137.

158. Van Muylem A, Knoop C, Estenne M: Early detection of chronic pulmonary allograft dysfunction by exhaled biomarkers. Am J Respir Crit Care Med 2007, 175:731-736.

159. Brugière O, Thabut G, Mal H, Marceau A, Dauriat G, Marrash-Chahla R, Castier Y, Lesèche G, Colombat M, Fournier M: Exhaled NO may predict the decline in lung function in bronchiolitis obliterans syndrome. Eur Respir J 2005, 25:813-819.

160. Verleden GM, Dupont LJ, Van Raemdonck DE, Vanhaecke J, Leuven Lung Transplant Group: Accuracy of exhaled nitric oxide measurements for the diagnosis of bronchiolitis obliterans syndrome after lung transplantation. Transplantation 2004, 78:730-733.

161. Gabbay E, Walters EH, Orsida B, Whitford H, Ward C, Kotsimbos TC, Snell Gl, Williams TJ: Post-lung transplant bronchiolitis obliterans syndrome (BOS) is characterized by increased exhaled nitric oxide levels and epithelial inducible nitric oxide synthase. Am J Respir Crit Care Med 2000, 162:2182-2187.

doi:10.1186/1824-7288-38-74

Cite this article as: Manna et al:: Clinical application of exhaled nitric oxide measurement in pediatric lung diseases. Italian Journal of Pediatrics $201238: 74$

\section{Submit your next manuscript to BioMed Central and take full advantage of:}

- Convenient online submission

- Thorough peer review

- No space constraints or color figure charges

- Immediate publication on acceptance

- Inclusion in PubMed, CAS, Scopus and Google Scholar

- Research which is freely available for redistribution 